\title{
A hitherto unknown river type from the Archaean at Bhurkuli (Jharkhand, E India)
}

\author{
A.J. (Tom) van Loon ${ }^{1,2 *}$, Shuvabrata $\mathrm{De}^{3}$ \\ ${ }^{1}$ College of Earth Science and Engineering, Shandong University of Science and Technology, No.579, Qianwangang \\ Road, Huangdao District, Qingdao, China 266590 \\ ${ }^{2}$ Geocom Consultants, Valle del Portet 17, 03726 Benitachell, Spain; e-mail: Geocom.VanLoon@gmail.com \\ ${ }^{3}$ CSIR-National Geophysical Research Institute, Uppal Road, Hyderabad 500007, India; e-mail: sderesf@gmail.com \\ *Corresponding author
}

\begin{abstract}
The Archaean granitoid pluton of the Singhbhum craton in E India is overlain by Archaean to Palaeoproterozoic metasediments. These sediments are still poorly known and their stratigraphy is under debate. Several scattered, most probably Meso- to Neoarchaean, conglomerates are present in the state of Jharkhand that differ so much in characteristics that they are probably not related to each other. The sedimentology of a series of conglomerate patches and layers near Bhurkuli has been investigated, including the characteristics of the clasts. It is deduced on the basis of these characteristics and the sedimentological context that the Bhurkuli conglomerates represent the channel facies of a river system that differed from the types of fluvial systems that exist nowadays.
\end{abstract}

Keywords: conglomerates, fluvial system, pebble characteristics, Precambrian, Singhbhum Craton

\section{Introduction}

Numerous conglomerates have been mentioned to be present in the Archaean sedimentary successions overlying the igneous cores of the various cratons in India (e.g. Srinivasan \& Naqvi, 1990; Naha et al., 1995; Vasudev \& Chadwick, 2008; Bhushan \& Sahoo, 2010), but only few have been the subject of modern geological research (e.g. Reddy et al., 2002; Mohapatra et al., 2008), and even less have been investigated sedimentologically in some detail (e.g. Chatterjee \& Das 2004; Van Loon et al., 2012; Van Loon \& De, 2015).

The Singhbhum craton in eastern India is no exception: the Archaean conglomerates received relatively little attention; some aspects dealt with in varying degrees of detail concern their stratigraphic significance (Sinha et al., 1997; Acharyya et al., 2010), the presence of pebbles derived from older iron-ore deposits (e.g. Mukhuopadhyay et al., 2007; Mohapatra et al., 2008) and their structural characteristics (Mukhyopadhyay et al., 1990), including deformation of pebbles (e.g. De, 1957). A typically sedimentological study carried out by Van Loon et al. (2012) concerned a conglomeratic succession at Rajkharsawan.

Dunn (1929) described already several exposures of Archaean conglomerates from Jharkhand in the northern Singhbhum area. Later investigations (Dunn \& Dey, 1942) have confirmed and extended the number of conglomerate occurrences, but these appear not always traceable nowadays, as some of the conglomerate bodies occur in densely vegetated areas, and the then authors did not provide precise locations.

Since the studies by Dunn, hardly any attention has been paid to these conglomerates, and a sedimentological approach was, as a rule, not followed 
at all. As mentioned above, a section with conglomerates near Rajkharsawan was analysed sedimentologically in detail (Van Loon et al., 2012), resulting in a reconstruction of the depositional environment (a meandering river system during or shortly after a phase with volcanic activity), and Bhattacharya \& Mahapatra (2008) described the Bisrampur conglomerate sedimentologically and tectonically (alluvial-fans/fan delta along the margin of a rift graben). Van Loon \& De (2015) summarized some characteristics of a dozen conglomerates in the state of Jharkhand (Fig. 1).

Here we present sedimentological data of a succession of Archaean conglomerates alternating with sandy schists exposed near the village of Bhurkuli, with the objective to reconstruct the processes that were involved in their formation, so as to reconstruct their depositional environment.

\section{Geological setting}

The sediments on the Singhbhum craton record sedimentation and volcanism in a changing tectonic setting during the Mesoarchaean-Mesoproterozoic (Eriksson et al., 1999; Mazumder et al., 2000; Mazumder, 2005). Analysis of the sedimentary development of the supracrustal succession seems the best way to unravel the early history of the area.
In the northern Singhbhum area (where the Bhurkuli conglomerate is situated), the Mesoarchaean volcano-sedimentary succession consists of the Iron Ore Group (IOG) that is characterised by banded iron formations (BIF), clastic sedimentary rocks (sometimes with volcanic components) and minor carbonates (Dunn, 1929; Dunn \& Dey, 1942; Chakraborty \& Majumder, 1986; Saha, 1994; Chakraborty, 1996; Roy \& Bhattacharya, 2012). The clastic rocks consist partly of conglomerates, particularly in the upper part of the IOG. Several granites have intruded the older rocks at different times, indicated as phases I-III in Figure 1.

Until recently, the Mesoarchaean was presumed to be followed in most of the Singhbhum supracrustal province by a number of formations (from old to young the Dhanjori, Chaibasa, Dhalbhum, Dalma and Chandil Formations) that are partly volcanic, partly sedimentary in origin, but all have undergone greenschist to amphibolite facies metamorphism (see Mazumder et al., 2012 - and references therein - for an overview). Only recently it appeared that a thick palaeosol is present on top of or - more probably - covering an erosional surface of the IOG (Van Loon et al., 2012). It seems likely that also the conglomerate under study here must be situated stratigraphically in the top part of the Iron Ore Group.
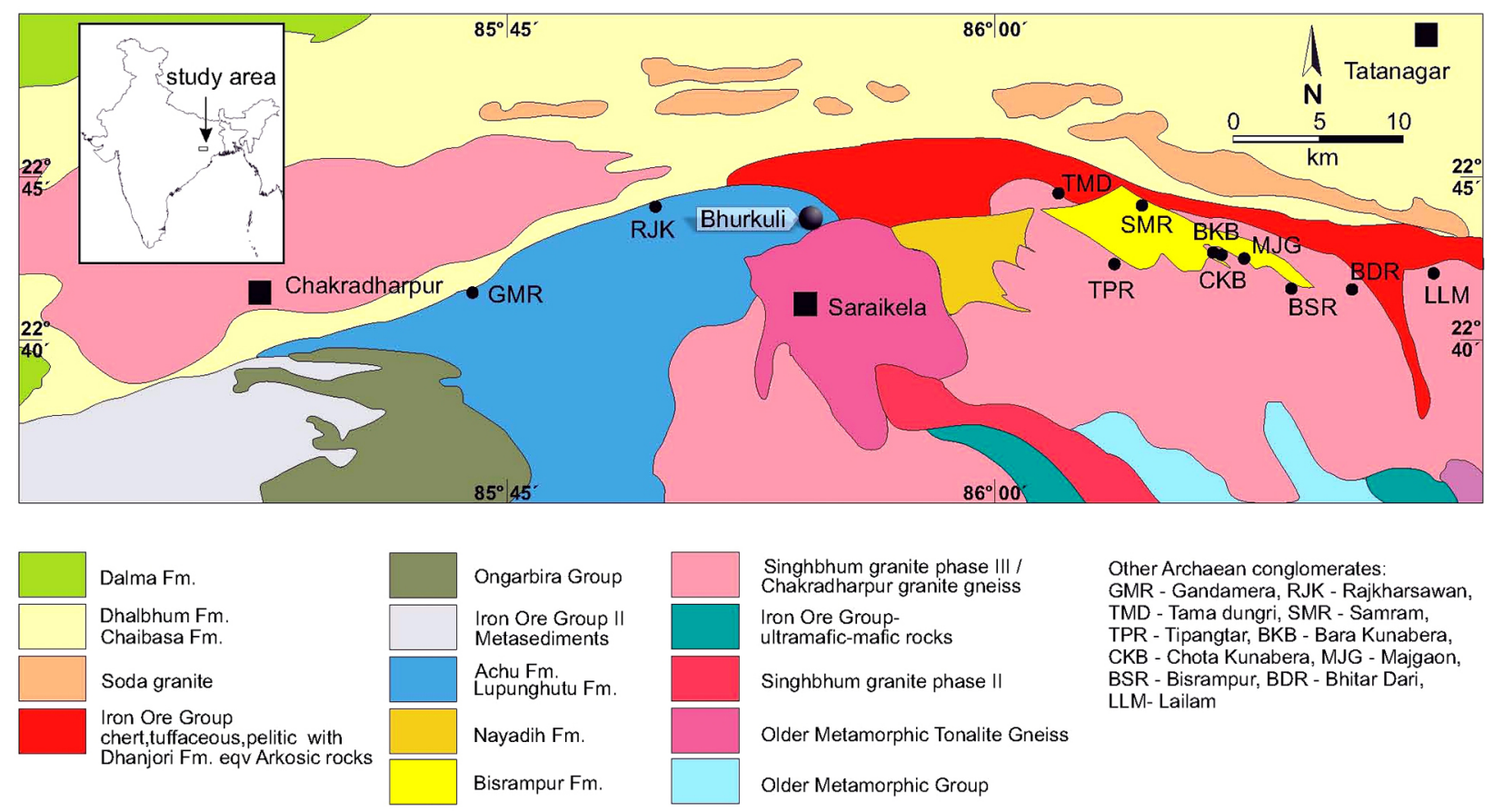

Singhbhum granite phase III / Chakradharpur granite gneiss Iron Ore Groupultramafic-mafic rocks

Singhbhum granite phase II

Older Metamorphic Tonalite Gneiss

Older Metamorphic Group

Fig. 1. Schematic geological map of the northern part of the Singhbhum craton between Chakradarpur in the West and Tatanagar in the East. The Bhurkuli conglomerate is situated seemingly in a belt of Archaean conglomerates that, however, are mutually not related. 


\section{The Bhurkuli conglomerate}

Dunn (1929) already mentioned some conglomerate outcrops near Bhurkuli (Fig. 2), roughly forming a (tilted) sedimentary succession in which the various conglomerate levels are separated by schists. Dunn tectonically connected the individual patches and layers of conglomerate, which are separated from one another by masses of sandy schists (greenschist facies) in which layering is no longer visible at most places, but sometimes discernible on the basis of laminae with different grain sizes, but it should be kept in mind that lamination in these rocks can also have resulted from tectonics.

Dunn assumed severe folding of the rocks. We measured bedding planes at several places, both by measuring the contacts between conglomerates and schists, and through the lamination in the schists. The structural position of the conglomerates varies (which makes a reliable reconstruction of the thicknesses of the various units impossible), but it appears particularly from the conglomerate levels that the sediments in the entire succession have an average strike that is roughly ESE-WNW, with a dip to the NNE of some $20-45^{\circ}$, with a range, however, of $0-60^{\circ}$.

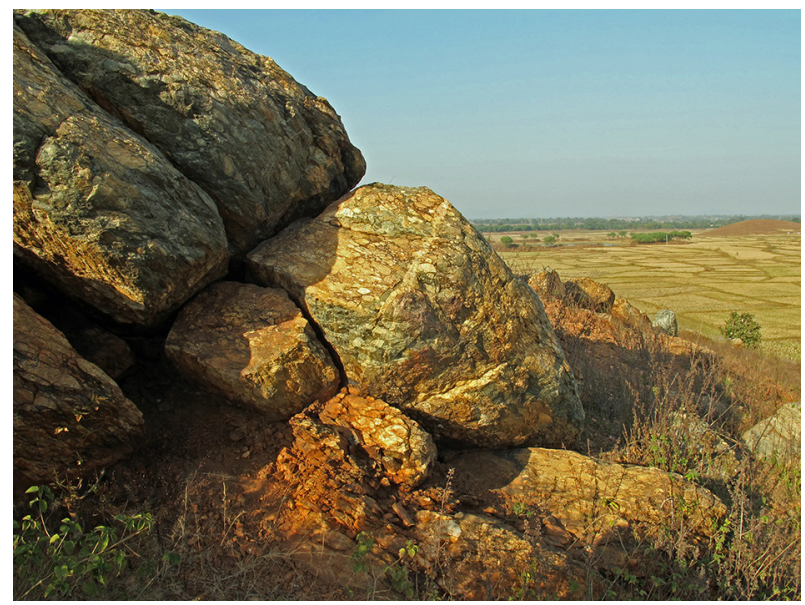

Fig. 2. Several of the exposures of the Bhurkuli conglomerate are exposed as isolated patches at hill tops between the sandy schists that tend to be covered by vegetation or that are used as arable land.

We found several conglomerate layers and patches exposed at a hill near Bhurkuli, eight of which were sufficiently exposed to carry out some measurements and/or to make some relevant observations. As mentioned above, the vegetation and some faulting make it impossible, however, to establish the precise thicknesses of the various conglomerate units; nor could their mutual vertical distances be determined with any reliability. We provide here first - as far as possible - the various characteristics of the exposed conglomerates.

\subsection{Bhurkuli-1}

This first exposure is situated at $22^{\circ} 43^{\prime} 35.5^{\prime \prime} \mathrm{N}$, $85^{\circ} 54^{\prime} 10.3^{\prime \prime} \mathrm{E}$. The conglomerate here is clast-supported and contains predominantly quartzite pebbles, with pebbles of vein quartz in minor quantities. Accessory pebbles consist of Banded Iron Formation (BIF) and of bright green (fuchsite-rich) quartz (Fig. 3). In the upper part of this conglomerate more variation in the pebble composition exists, with particularly some more BIF pebbles. Locally the conglomerate has undergone such a degree of metamorphism that it cannot be established with certainty with the naked eye whether the rock is a recrystallised conglomerate with pebbles exclusively consisting of vein quartz or a very clean quartzite within a matrix of pure quartz sandstone, or whether it is a quartz vein (quartz veins abound in the conglomerate) (Fig. 4). The conglomerate is embedded in a schist of greenschist facies.

We measured a contact plane between what is probably a conglomerate layer and the underlying schist. The plane probably represents a bedding plane, but a tectonic nature cannot be fully excluded, as several planes with slickensides are present elsewhere in this conglomerate. The contact plane has a $005^{\circ} / 45^{\circ}$ position; this means: a tilt with a dip direction towards $005^{\circ}$ (= almost to the North with

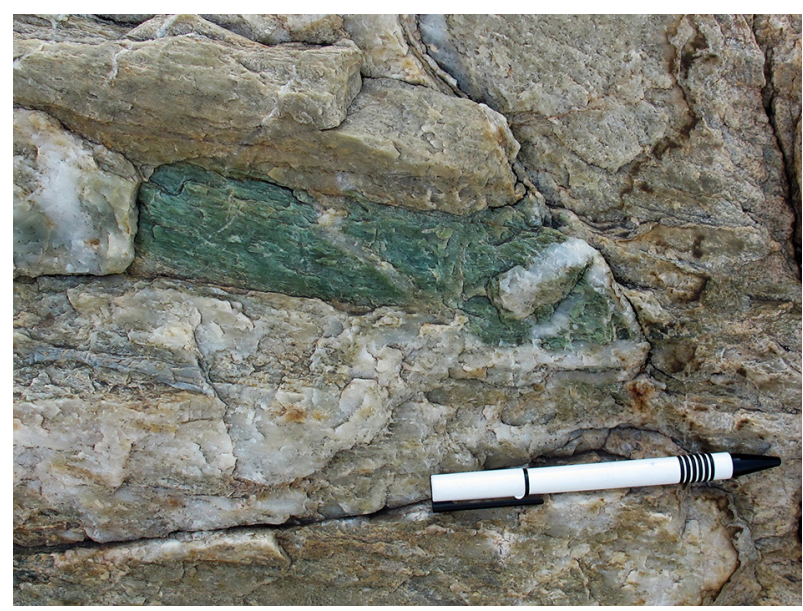

Fig. 3. A characteristic, though relatively rare, component of the Bhurkuli conglomerates is a green variety of quartz (rich in fuchsite), present as clasts of up to about $2 \mathrm{dm}$ long. The presence (in different concentrations) or absence of this green quartz in the various levels of the Bhurkuli conglomerates is an indication for supply from different source areas. 


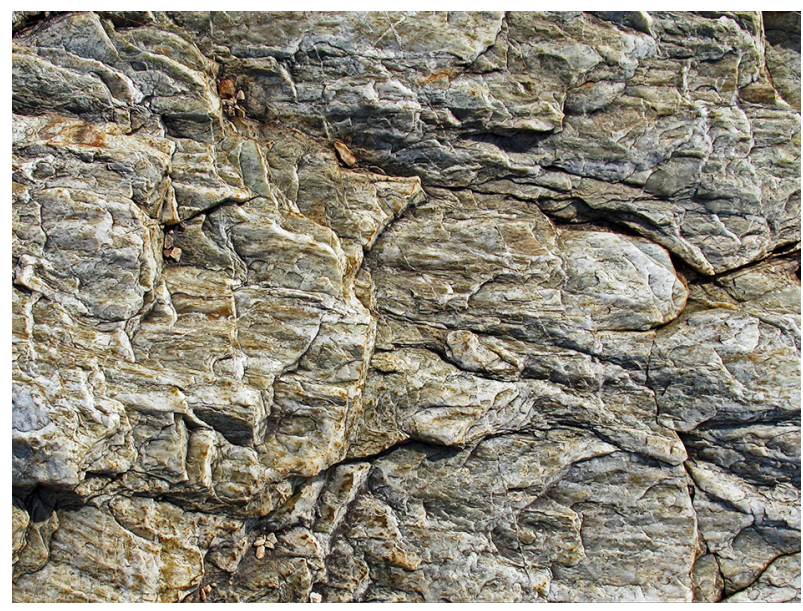

Fig. 4. Some of the conglomerate levels consist of almost exclusively white quartzite and vein-quartz pebbles within a quartz matrix, sometimes (like here) preventing to distinguish between the metamorphosed pebbles and matrix, and occasionally resembling wide quartz veins.

a $5^{\circ}$ angle towards the East) and an inclination of $45^{\circ}$. The schists overlying this conglomerate were measured as $020^{\circ} / 15^{\circ}$; the contact plane between these schists and the conglomerate unit is not exposed.

\subsection{Bhurkuli-2}

All conglomerates occur in a fairly small area. This second exposure is located close to site Bhurkuli-1, at $22^{\circ} 43^{\prime} 37.1^{\prime \prime} \mathrm{N}, 85^{\circ} 54^{\prime} 12.1^{\prime \prime} \mathrm{E}$. The overall position of the bedding planes is $020^{\circ} / 20^{\circ}$.

This clast-supported conglomerate unit poses an intriguing problem. A first impression is that the conglomerate has suffered more from tectonics than did the rocks of Bhurkuli-1, as indicated by the occurrence of levels with strongly flattened pebbles (a representative pebble has an a-axis of $32 \mathrm{~cm}$, a b-axis of $10 \mathrm{~cm}$, and a c-axis of $2 \mathrm{~cm}$ ). This flattening (Fig. 5) should, however, if due to tectonic stretching like in the case of the Rajkharsawan conglomerate (Van Loon et al., 29012), occur in the entire conglomerate (cf. Cowan, 1978; Reimer et al., 1985; McCann \& Kennedy, 2009), but this is not the case: similar flattening of the pebbles has been found only in one other exposure of the Bhurkuli conglomerates; moreover, this feature is not present in all levels of Bhurkuli-2. This seems to exclude a tectonic origin after deposition of the conglomerate unit, suggesting that the flattening is inherited: a conglomerate in a not too remote source area may have been affected by strong tectonism that led to fairly extreme flattening of the pebbles (like in the Rajkharsawan conglomerate described by Van Loon et al., 2012), and that streams (no other medium seems applicable, as will be detailed further on) transported these flattened pebbles and deposited them at the Bhurkuli-2 site, without having sufficient time to give the pebbles a more common fluvial shape.

As not all levels at Bhurkuli-2 have flattened pebbles, this must be explained by changes in the source areas of the medium that transported the pebbles. This is interesting, as this gives some clues about the depositional environment. This will be dealt with in more detail in the Discussion section.

In spite of the above, some tectonics have affected this site, indeed, as folding can be observed in a sandy schist unit. The axis of the (small) fold is bent, from $080-260^{\circ} / 80^{\circ}$ to $060-240^{\circ} / 60^{\circ}$. This has, however, been found at one place only.

\subsection{Bhurkuli-3}

Bhurkuli-3 is a clast-supported conglomerate unit located at $22^{\circ} 43^{\prime} 39.1^{\prime \prime} \mathrm{N}, 85^{\circ} 54^{\prime} 09.0^{\prime \prime} \mathrm{E}$. The bedding plane is orientated $010^{\circ} / 25^{\circ}$. This is the only site in the Bhurkuli section where sufficient pebbles could be isolated from the rock (at other places they are too much jointed, so that they crumble when taken from the rock, or they are so 'amalgamated' with the quartz cement that they cannot be isolated

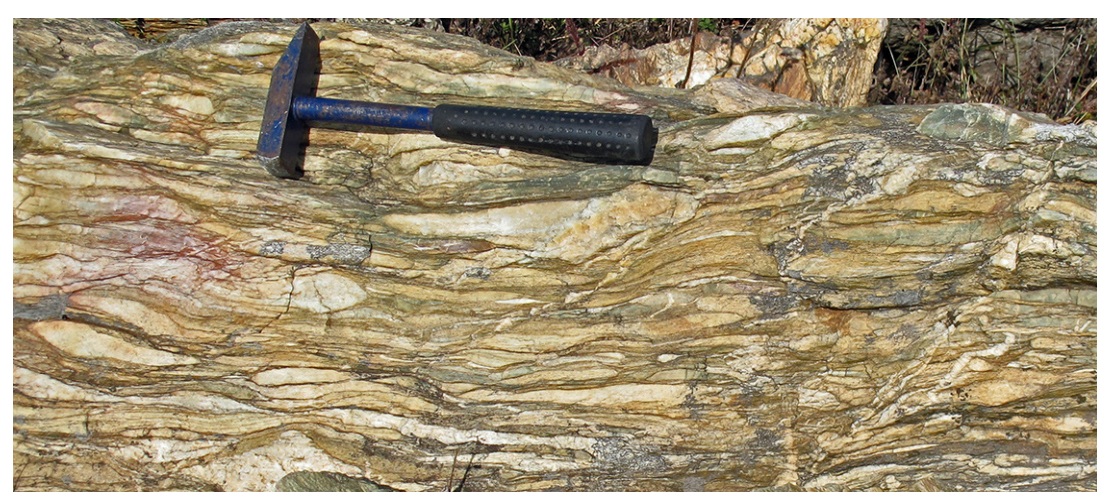

Fig. 5. Some levels of the Bhurkuli-2 conglomerate contain these tectonically strongly flattened pebbles, whereas other levels contain only pebbles that do not show such flattening, indicating that the flattening cannot be the result of deformation in situ, but that exceptionally flattened pebbles must have been supplied by the stream from a source area where the pebbles were already tectonically flattened. 
Table 1. Sizes, measurements of axes, calculations and statistical values regarding the shape of the 20 largest pebbles that could be isolated from the Bhurkuli-3 conglomerate. Flatness Index $F=(a+b) / 2 c$ (Cailleux, 1945); flatness ratio $[(a-b) /(a-c)]$ (Wentworth, 1922); maximum projection sphericity $\Psi=\left(c^{2} / a b\right)^{1 / 3}$; oblate-prolate index: OPI = $10[\{\{(a-b) /(a-c)\}-0.5\} /\{c / a\}$ (Dobkins \& Folk, 1970).

\begin{tabular}{|c|c|c|c|c|c|c|c|c|c|}
\hline & 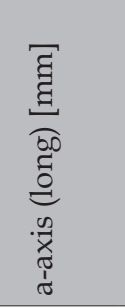 & 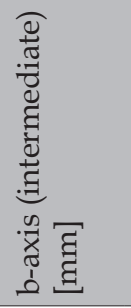 & 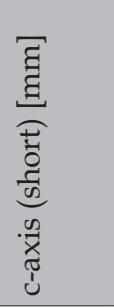 & $\begin{array}{l}\stackrel{0}{\pi} \\
\stackrel{\pi}{0} \\
\frac{\sigma}{\sigma}\end{array}$ & 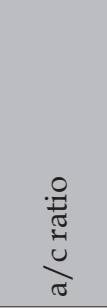 & 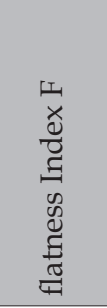 & 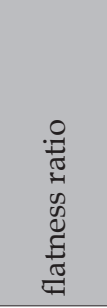 & 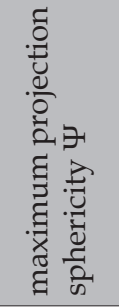 & $\begin{array}{l}\circlearrowright \\
0 \\
0 \\
0 \\
0 \\
\frac{0}{0} \\
0 \\
0 \\
1 \\
0 \\
\frac{\pi}{0} \\
0\end{array}$ \\
\hline & 180 & 45 & 25 & 4 & 7.2 & 4.5 & 0.871 & 0.4257 & 26.7097 \\
\hline & 135 & 37 & 19 & 3.6487 & 7.1053 & 4.5263 & 0.8448 & 0.4165 & 24.5009 \\
\hline & 130 & 58 & 32 & 2.2414 & 4.0625 & 2.9375 & 0.7347 & 0.5140 & 9.5344 \\
\hline & 122 & 39 & 22 & 3.1282 & 5.5455 & 3.6591 & 0.83 & 0.4668 & 18.3 \\
\hline & 120 & 51 & 17 & 2.3529 & 7.0588 & 5.0294 & 0.6699 & 0.3615 & 11.9931 \\
\hline & 116 & 78 & 40 & 1.4872 & 2.9 & 2.425 & 0.5 & 0.5613 & 0. \\
\hline & 105 & 53 & 16 & 1.9811 & 6.5625 & 4.9375 & 0.5843 & 0.3583 & 5.5302 \\
\hline & 83 & 60 & 23 & 1.3833 & 3.6087 & 3.1087 & 0.3833 & 0.4736 & -4.2101 \\
\hline & 66 & 37 & 17 & 1.7838 & 3.8824 & 3.0294 & 0.5918 & 0.491 & 3.5654 \\
\hline & 66 & 36 & 24 & 1.8333 & 2.75 & 2.125 & 0.7143 & 0.6235 & 5.8929 \\
\hline & 66 & 18 & 12 & 3.6667 & 5.5 & 3.5 & 0.8889 & 0.4949 & 21.3889 \\
\hline & 64 & 31 & 17 & 2.0645 & 3.7647 & 2.7941 & 0.7021 & 0.5262 & 7.6095 \\
\hline & 60 & 42 & 15 & 1.4287 & 4.0 & 3.4 & 0.4 & 0.447 & -4.0 \\
\hline & 59 & 31 & 14 & 1.9032 & 4.2143 & 3.2143 & 0.6222 & 0.475 & 5.1508 \\
\hline & 56 & 32 & 11 & 1.75 & 5.0909 & 4.0 & 0.5333 & 0.4072 & 1.697 \\
\hline & 55 & 30 & 18 & 1.8333 & 3.0556 & 2.3611 & 0.6757 & 0.5812 & 5.3679 \\
\hline & 55 & 28 & 17 & 1.9643 & 3.2353 & 2.4412 & 0.7105 & 0.5725 & 6.8111 \\
\hline & 51 & 18 & 11 & 2.8333 & 4.6364 & 3.1364 & 0.825 & 0.5089 & 15.068 \\
\hline & 45 & 21 & 16 & 2.1429 & 2.8125 & 2.0625 & 0.8276 & 0.6470 & 9.2134 \\
\hline & 41 & 21 & 10 & 1.9524 & 4.1 & 3.1 & 0.6452 & 0.4879 & 5.9516 \\
\hline Mean & 83.75 & 38.3 & 18.8 & 2.2690 & 4.5543 & 3.3144 & 0.6777 & 0.4920 & 8.8037 \\
\hline Median & 66 & 36.5 & 17 & 1.9727 & 4.0813 & 3.1225 & 0.6889 & 0.4894 & 6.3814 \\
\hline Mode & 66 & 37 & 17 & & & & & & \\
\hline Std dev $\left(\sigma^{2}\right)$ & 37.172 & 15.205 & 7.173 & 0.7540 & 1.4463 & 0.8703 & 0.1449 & 0.0768 & 8.4033 \\
\hline
\end{tabular}

without being too severely damaged) to allow some measurements of their shapes. Fortunately, the pebbles at this site seem fairly representative for the entire group of Bhurkuli conglomerates as far as their sizes, rounding and flattening are concerned (they are not exceptionally flattened such as the pebbles in some levels of Bhurkuli-2).

For the measurements, we selected the largest quartzite pebbles that could be isolated from the rock. The measurements are given in Table 1 , which also provides the relevant calculations and statistical outcomes. The significance of these data for the interpretation of the depositional environment is dealt with in detail in Section 5 (Depositional environment). Let it suffice here to mention that it appears that there are some relationships between pebble size and shape. All pebbles show a considerable degree of flattening (the lowest a/c ratio is 2.81). Such flat- tening - if not tectonically influenced, which seems not the case in this conglomerate unit, but which is present in some other units - can result from fluvial transport and from exposure to wave action on a gravel beach. It is interesting to note that there is a tendency for the pebbles to become less flattened with decreasing size. It is also interesting that the shape of the a/b-planes, which indicates elongation of the clasts, is limited, with 4.00 as a maximum and 1.49 as a minimum. Here, too, a slight tendency of decreasing elongation with clast size is present.

\subsection{Bhurkuli-4}

The fourth exposure of the conglomerate is situated at $22^{\circ} 43^{\prime} 43.4^{\prime \prime} \mathrm{N}, 85^{\circ} 54^{\prime} 09.5^{\prime \prime} \mathrm{E}$. Bedding planes are well exposed, and show an average orientation 
of $000^{\circ} / 20^{\circ}$ with only a few degrees variation. The pebbles of the clast-supported conglomerate are almost all positioned parallel to subparallel to the bedding plane, so that their a-axes and b-axes can be measured well. It appeared impossible, however, to isolate sufficient pebbles from the rock for statistically reliable measurements of their shapes: they fell into pieces because of the system of closely spaced joints. On the basis of what could be seen and isolated, we deduce that the conglomerate resembles that of site Bhurkuli-3.

\subsection{Bhurkuli-5}

Site Bhurkuli-5 is situated at $22^{\circ} 43^{\prime} 41.9^{\prime \prime} \mathrm{N}$, $85^{\circ} 54^{\prime} 18.2^{\prime \prime} \mathrm{E}$. In contrast to the sites Bhurkuli-1 to Bhurkuli-4, the conglomerate shows, although overall clast-supported, frequent intercalations of sandy schists, which allows a reliable measurement of the bedding plane; this is fairly consistently $040^{\circ} / 45^{\circ}$.

The conglomerate consists almost exclusively of quartzite and quartz pebbles, with other lithologies only as accessory clasts. Particularly the conglomerate levels, but to a lesser degree also the schists, show numerous quartz veins (Fig. 6). These have for the great majority roughly the same orientation: $035^{\circ} / 90^{\circ}$.

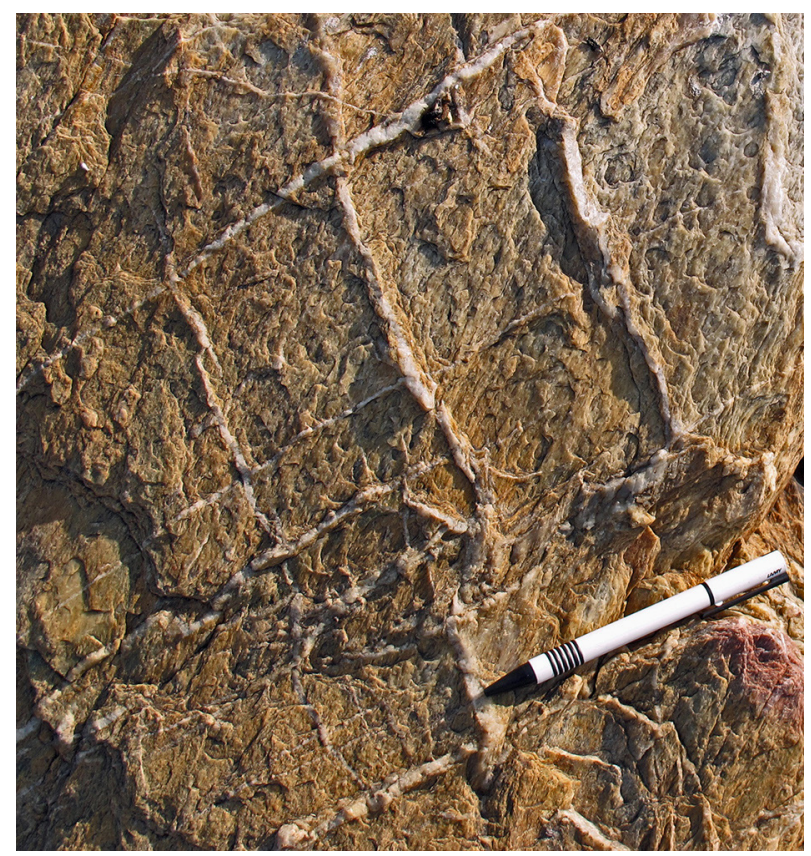

Fig. 6. Particularly at site Bhurkuli-5 quartz veins, sometimes forming networks, are common.

\subsection{Bhurkuli-6}

Bhurkuli-6 is situated at $22^{\circ} 43^{\prime} 43.2^{\prime \prime} \mathrm{N}$, $85^{\circ} 54^{\prime} 21.5^{\prime \prime} \mathrm{E}$. The position of the clast-supported conglomerate beds varies around $015^{\circ} / 25^{\circ}$. The source of the pebbles apparently had changed, as indicated not only by a smaller size (the largest pebble that we observed had an a-axis of 'only' $44 \mathrm{~cm}$ ), but the clasts show much more variation in lithology (Fig. 7) than do the clasts of Bhurkuli-1 to Bhurkuli-5. A remarkable feature is that some pebbles are exceptionally flattened, whereas other pebbles are not; this difference in shape must be ascribed to the supply of pebbles with different degrees of flattening, as the flattening cannot be ascribed to post-depositional tectonic stretching.

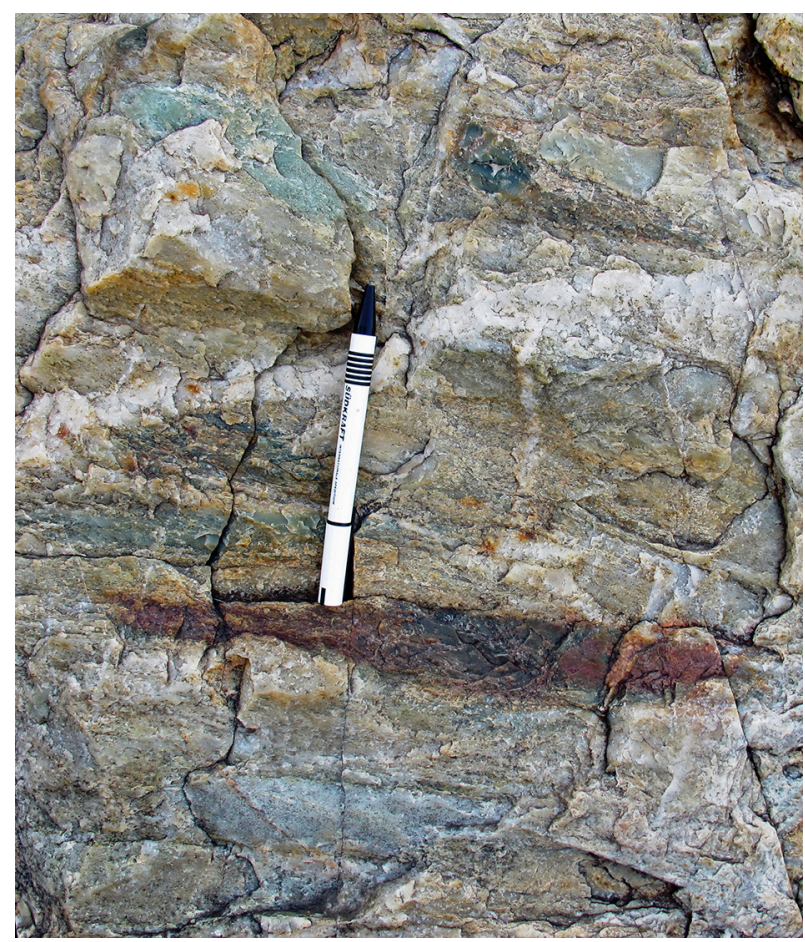

Fig. 7. The Bhurkuli-6 conglomerate has a much larger concentration of 'uncommon' clasts than do the conglomerates at lower stratigraphic levels. Some of the pebbles are uncommonly flattened, whereas others are not. This indicates that the flattening cannot be due to tectonic deformation in situ, but that some pebbles were derived from rocks in which they had already obtained a flattened shape by tectonic activity.

\subsection{Bhurkuli-7}

This exposure, an isolated outcrop between vegetated sandy schists, at $22^{\circ} 43^{\prime} 49.1^{\prime \prime} \mathrm{N}, 85^{\circ} 54^{\prime} 26.0^{\prime \prime} \mathrm{E}$ is so small that no bedding plane could be measured. It is a typical clast-supported quartzite con- 
glomerate, though other pebble types are also present. These pebbles with other lithologies are less common than at site Bhurkuli-6, but more common than at sites Bhurkuli-1 to Bhurkuli-5.

\subsection{Bhurkuli-8}

The Bhurkuli-8 site is situated at a hill top at $22^{\circ} 43^{\prime} 55^{\prime \prime} \mathrm{N}, 85^{\circ} 54^{\prime} 30.0^{\prime \prime} \mathrm{E}$. It is the stratigraphically highest exposure of these conglomerates, which consist here predominantly of quartzite and vein quartz pebbles. The clast-supported conglomerate beds show clear bedding planes varying around $010^{\circ} / 25^{\circ}$. The last conglomerate bed has a contact with the overlying schists (Fig. 8). At this contact plane, which is situated at $85^{\circ} 43^{\prime} 35.9^{\prime \prime} \mathrm{N}$, $22^{\circ} 54^{\prime} 29.0^{\prime \prime} \mathrm{E}$, the position is $015^{\circ} / 40^{\circ}$.

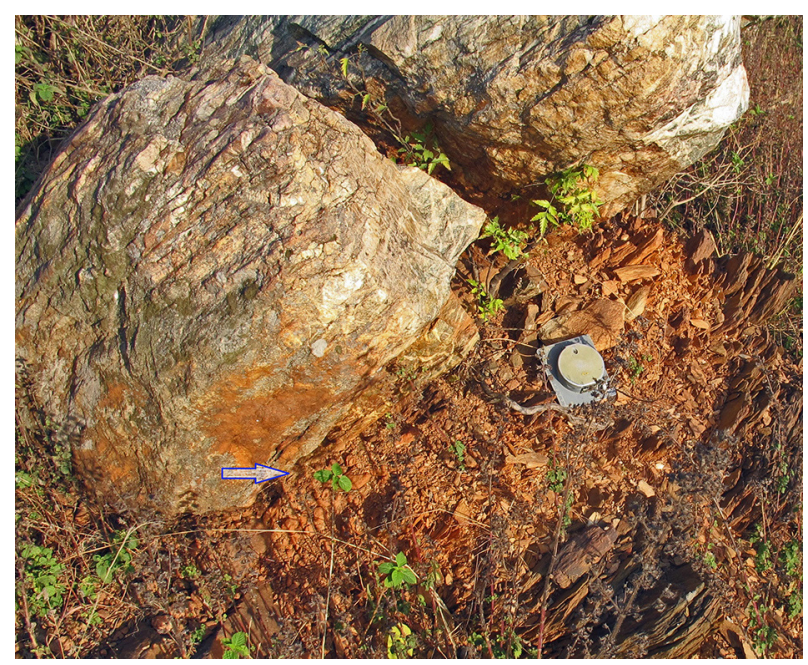

Fig. 8. The contact between the uppermost conglomerate of Bhurkuli-8 and the overlying sandy schists. This contact seems sedimentary, not tectonic.

The resemblance of this conglomerate with the Rajkharsawan conglomerate (Van Loon et al., 2012), which is situated somewhat less than $10 \mathrm{~km}$ to the West (Fig. 1) in the same 'belt' with Archaean conglomerates (see also Van Loon \& De, 2015) is striking, regarding the clast-supported character of almost all conglomeratic beds, the local occurrence of tectonically flattened pebbles and the presence of schists that are embedding the conglomeratic units.

\section{Structural aspects}

In order to explain the vertical (though tilted) alternation of conglomerate patches and schists,
Dunn (1929) assumed a tectonic structure that was characterised by a large, wide fold. We did not find any evidence for this. On the contrary, the various outcrops make it highly unlikely that such a fold exists, because the different outcrops (which we assume to represent successive stratigraphic levels) differ in composition of the conglomerate clasts and in other aspects such as the size of the clasts, the concentration of veins, the presence of schist layers in the conglomerates, etc. The lowermost (exposed) conglomerate consists almost exclusively of quartzite pebbles, whereas higher up in the succession more clasts of different types occur (e.g. BIF, bright green, fuchsite-rich quartz). The rocks have, however, been affected by tectonics (as shown by faults with slickensides: Fig. 9), among others at the contact between the greenschist and the lowermost conglomerate. The deformation has locally even been so intense that it is at some places not possible to establish in the field with certainty whether a level consists of recrystallized quartz pebbles or whether the level represents a quartz vein (indisputable quartz veins are present).

The presence of tectonic features, such as closely spaced joints in the pebbles, slickensides at contacts and small folds, implies that the influence of tectonic activity on the present-day characteristics of the conglomerates should not be neglected. Therefore measurements of bedding planes should be interpreted with utmost care, the more so because apparent lamination in the schistose rocks may have a tectonic origin. Our observations indicate, however, that there is no reason to assume that the tectonics have affected the succession in a way that disturbed the original succes-

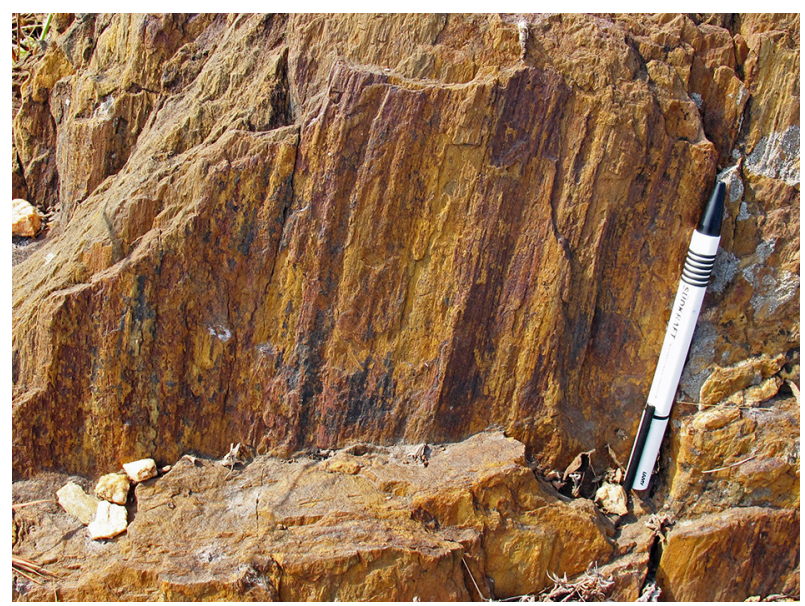

Fig. 9. Slickensides indicate that tectonic deformation resulted in faulting, but the displacement due to the faulting cannot be established. 


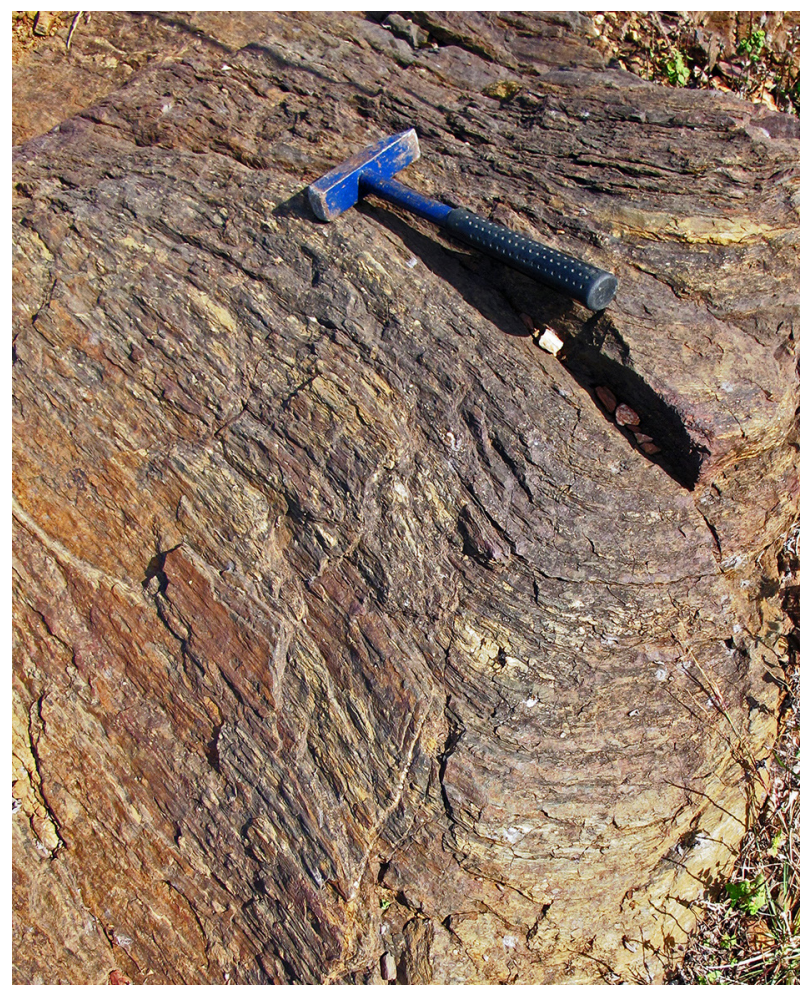

Fig. 10. One of the rare folds, which seem to have only small effects on both the tectonic position of the individual layers and the overall succession.

sion by significant faulting or by overturned folds that might result in duplicate presence of specific stratigraphic levels within the section investigated in the field: all bedding planes that can be measured, both by contacts between the conglomerates and the schists and through the lamination in the schists, show a strike that is roughly ESE-WNW, with a dip to the NNE of commonly some $20-45^{\circ}$. Some relatively small folds are present, and a small, bent fold axis (with a direction changing from $080-260^{\circ}$ to $060-240^{\circ}$ ) has been measured in sandy greenschists (Fig. 10). These small structural features only locally disturb the general strike and dip of the rocks.

One specific feature deserves attention: when going from site Bhurkuli-1 to Bhurkuli-8, the successive conglomerates are situated roughly on top of each other (separated by schist units), but they extend to different distances at the eastern side. At their western sides, however, most of the conglomerates have a fairly equal lateral extent (some extend a bit less to the West than do the other Bhurkuli conglomerates), and it cannot be fully excluded that a fault is present that cuts of the westernmost parts of some of the conglomerate levels; the bad degree of exposure prevents, however, to establish this with some certainty.

\section{Depositional environment}

Conglomerates occur in all depositional environments, if only because of downslope movement of gravelly sediments in the form of mudflows or other forms of mass transport. No indications for mass transport have been found in the Bhurkuli conglomerates, however. This excludes a deeper-marine environment. A near-coast marine environment seems also unlikely, because no indications of wave activity (in the form of wave ripples or wave-induced sorting) have been found. Moreover, the relatively large size of the pebbles (order of a decimetre) can be explained in a near-coast marine environment only if supplied by mass flows or if a nearby hard-rock coast is eroded so that a pebble beach is formed. As mentioned above, no indications for mass transport have been found, however. On the contrary, the dense packing of the clasts in most conglomerates (Fig. 11), in combination with their orientation (commonly parallel or subparallel to the bedding plane, with locally some imbrication still being visible) clearly suggests transport as bed load or deposition on a pebble beach. This leaves the question of whether the Bhurkuli conglomerates represent a beach or a fluvial environment.

One clear difference between beach and fluvial pebbles was found already by Dobkins \& Folk (1970); more data were provided later by Widera (2010; see also the references therein): beach pebbles tend to be much more oblate (disc-like) than fluvial pebbles, that tend to be more prolate (rod-like), which offers an opportunity to distinguish between these depositional environments if sufficient other sedimentological criteria are absent. The difference

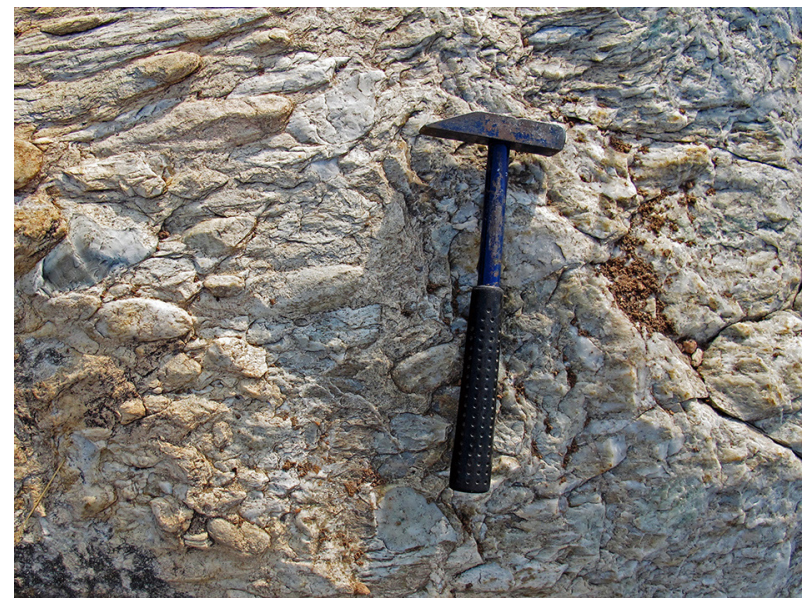

Fig. 11. The dense packing of the pebbles in most of the conglomerates, in combination with the almost total absence of fine-grained material in the matrix, indicates that the conglomerates have not been deposited by gravity flows. 
between the two pebble shapes is caused by the dominant processes in the environments: relatively large pebbles tend to slide over each other on a beach due to the continuous swash and backwash due to waves, whereas pebbles in a river tend to roll under the influence of continuous current activity. This aspect of the pebbles' shape is indicated by the ratio between the a-axis and the b-axis (the a-, band c- axes are the three perpendicular axes which are, respectively, the longest, the intermediate and the shortest). The measurement of the Bhurkuli-3 conglomerate pebbles (Table 1) indicates that a relationship exists, though it is not very clear, between the length of the pebbles and their $a / b$ ratio: the larger the pebble, the higher the $\mathrm{a} / \mathrm{b}$ ratio (Fig. 12). This is of interest, as larger pebbles tend to obtain the shapes that are characteristic for depositional and particularly transport processes more distinctly than do smaller pebbles (which are more easily affected by incidental processes because these tend to have a lower average energy). Another, related parameter is the flatness of the pebbles (or its reverse: the sphericity). Waves reaching a pebble beach make more or less spherical pebbles on a pebble beach continuously rolling, thus increasing their sphericity; flat pebbles move predominantly by sliding due to wave action, thus making them continuously flatter. In streams only uncommonly large pebbles (dm scale) are moved mainly by slid-

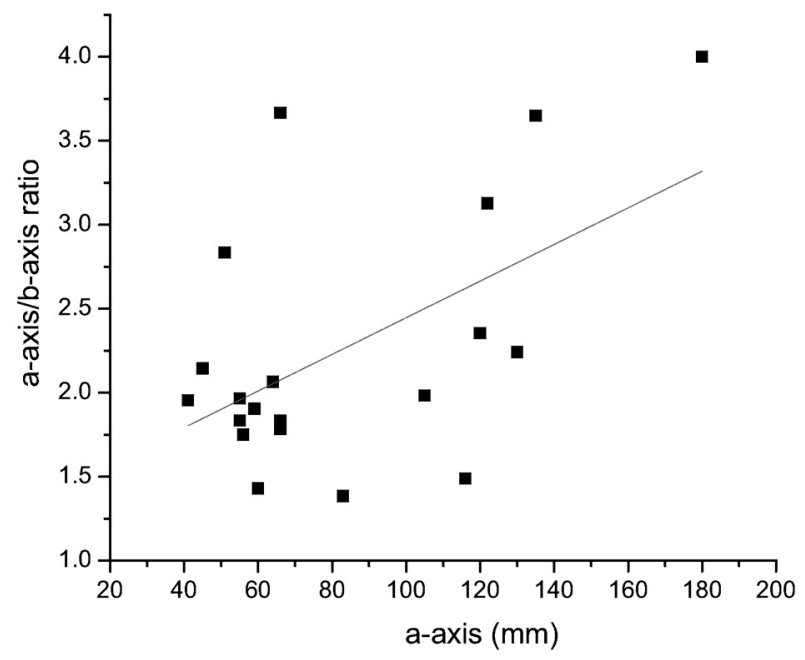

Fig. 12. The pebbles of the Bhurkuli-3 conglomerate tend to be more rod-like (higher $\mathrm{a} / \mathrm{b}$ ratio) with increasing size. This must be ascribed to transport in a stream where the pebbles moved as bed load by rolling around their a-axis, so that particularly the b- but also the c-axes became shorter. Linear fitting curve with $\mathrm{y}=\mathrm{a}+\mathrm{bx} . \mathrm{y}(=$ intercept $)=1.35527$ and $\mathrm{b}(=$ slope $)=$ 0.01091 . Adjusted $R^{2}=0.24976$, depicting a fairly large variance in the samples. ing. The ratio between the a-axis and the c-axis expresses whether a pebble commonly rolled or slid. Also regarding this aspect it turns out that the a/c ratio tends to be higher for large pebbles of the Bhurkuli-3 conglomerate than for smaller ones (Fig. 13). Combining the data for the $\mathrm{a} / \mathrm{b}$ and the $\mathrm{a} / \mathrm{c}$ ratio with the pebble size, it appears, consequently, that the ratio between the $a / c$ ratio and the $a / b$ ratio tends to increase with pebble size (Fig. 14), indicating that both the $a / b$ and the $a / c$ ratio are good indicators for the transport process and/or the depositional environment. This is relevant, because the oblate-prolate index, plotted against the maximum sphericity projection (Fig. 15), indicates clearly that the Bhurkuli-3 conglomerate is much more characteristic of a fluvial than of a beach environment.

If the conglomerates are fluvial, indeed, it might, in principle, also be possible that the conglomerates represent the lag deposits in the channels of a delta that discharged into the sea. The succession does, however, not show any characteristics of a deltaic development, nor are there any deltaic subenvironments that might be expected, either in the delta plain (e.g. fine-grained sediments in interdistributary bays) or on the delta slope (slumps and other mass-transported deposits). It must therefore be deduced that the conglomerates under study cannot have been deposited in a deltaic/marine environment.

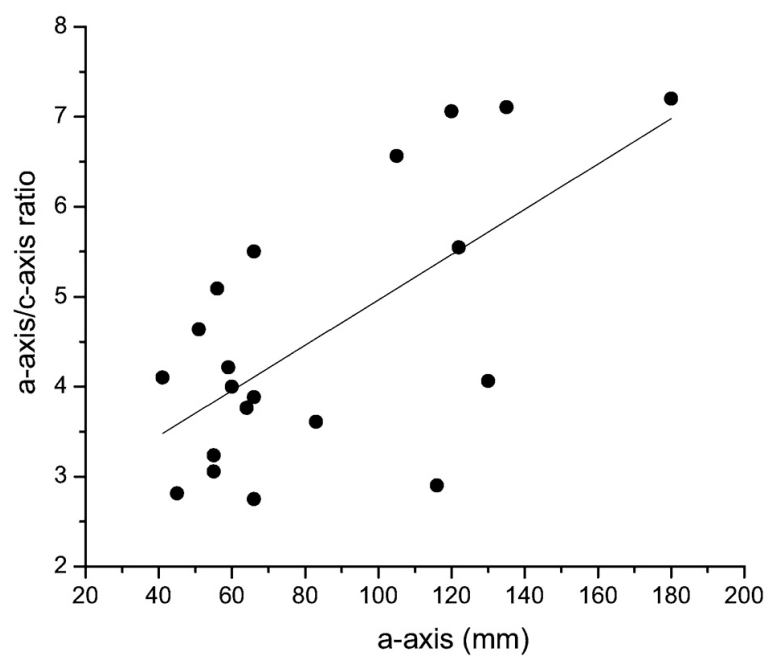

Fig. 13. The pebbles of the Bhurkuli-3 conglomerate tend to be more flattened (high a/c ratio) with increasing size. This must be ascribed to transport in a stream where the largest pebbles moved mainly as sliding bed load so that the c-axis became shorter, whereas smaller clasts moved more by rolling, thus shortening both their $b$ - and their c-axis. Linear fitting curve with $\mathrm{y}=\mathrm{a}+\mathrm{bx} . \mathrm{y}(=$ intercept $)=2.44485$ and $\mathrm{b}(=$ slope $)=$ 0.02519 . Adjusted $R^{2}=0.38678$, depicting the variance in the samples. 


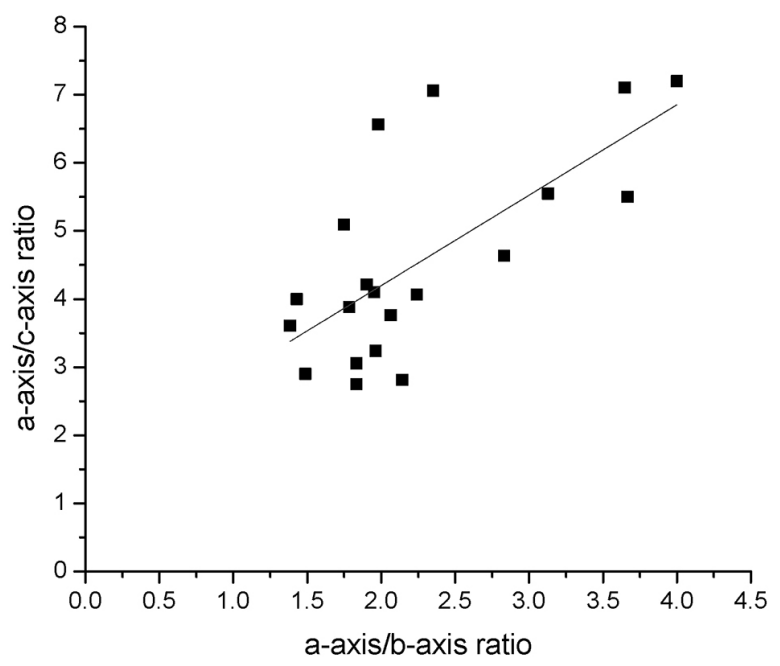

Fig. 14. Plot of the elongation $(a / b$ ratio) of the Bhurkuli-3 pebbles against their flatness (a/c ratio), showing the flattening increases with pebble size. The values suggest fluvial transport. Linear fitting curve with y $=\mathrm{a}+\mathrm{bx} \cdot \mathrm{y}(=$ intercept $)=1.54157$ and $\mathrm{b}(=$ slope $)=$ 1.32779. Adjusted $R^{2}=0.45028$, depicting the variance in the samples.

Continental conglomerates (excluding masstransported sediments and glacial tills (which are certainly not represented by the sediments under study) must have been deposited by streams, either in the most proximal environment (alluvial fans) or in a more distal fluvial environment. The characteristics and particularly the good rounding of the pebbles, in combination with the extent of the conglomerates and the alternation of conglomerates with very little matrix and sandy schists devoid of pebbles, indicate that the sediments did not accumulate on an alluvial fan. They must consequently represent deposits that accumulated in a less proximal fluvial environment.

This raises first the question of whether the sediments represent a meandering river, a braided river, an anastomosing river, or possibly a different type that does not resemble a modern river. For the purpose, the various characteristics of the Bhurkuli conglomerates (the interbedded sandy schists are hardly exposed and do not provide any sedimentological clue) are compared here with the characteristics of the conglomerates (or gravels) deposited by the various types of fluvial systems.

Although it has been questioned whether true meandering rivers could exist in Precambrian times, analysis of the Rajkharsawan conglomerate (Van Loon et al., 2012) made clear that such rivers existed, indeed. However, the Rajkharsawan conglomerates have more clearly developed, thick conglomerate lenses with erosional bases, whereas the Bhurkuli conglomerates have in general a more tab-

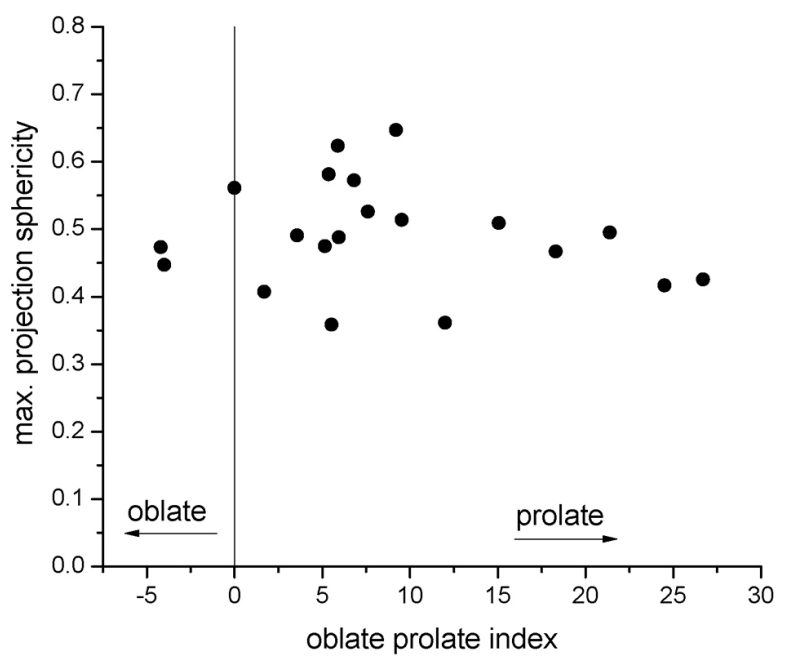

Fig. 15. Plot of the sphericity of the Bhurkuli-3 pebbles against their oblate-prolate index, indicating that the great majority of the pebbles have a prolate shape, with a small amount of oblate pebbles. This suggests that the clast population was primarily transported in a fluvial environment.

ular shape, with a much less clearly developed erosional basis (if erosional at all), and a more limited thickness. They thus are, although resembling the Rajkharsawan conglomerates in many respects, not characteristic of meandering rivers. Moreover, natural levees and point bars, which are characteristic of meandering rivers (Bluck, 1971; Miall, 2013), cannot be traced in the Bhurkuli section. It thus must be deduced that the Bhurkuli conglomerates do not represent the channel lags of meandering rivers.

Neither do the Bhurkuli conglomerates show the typical features of a braided system: the sediments consist of conglomerates and sandy schists, with hardly any intermediate forms, and the tabular conglomerate units are much more regular (Fig. 16) than is common for braided rivers (Miall, 1977; Leleu et al., 2009). Moreover, the good rounding of the great majority of the pebbles is not common for braided-river deposits, particularly because pebbles in a braided system tend to have been transported not yet very far (at least on average), certainly in comparison with pebbles in a meandering system.

A river type intermediate between meandering and braided, often referred to as a wandering river, has a gravel bed, but the characteristics of the floodplains (Nanson \& Croke, 1992) differ completely from those of the sandy schists that occur between the Bhurkuli conglomerates. Moreover, the pebble-sized clasts occur mainly scattered (Brierley, 1989; Desloges \& Church, 1989) in more finegrained sediment (mostly sand), which is inconsistent with the lithology of the Bhurkuli sediments. It 
Fig. 16. Most conglomerates form more or less tabular bodies of relatively small lateral extent, limited thickness and with a base that is commonly insufficiently well exposed to establish whether it is erosional; the shapes of the lower boundaries do not indicate strong erosion, which suggests that no significant channelling was present in the fluvial depositional environment.

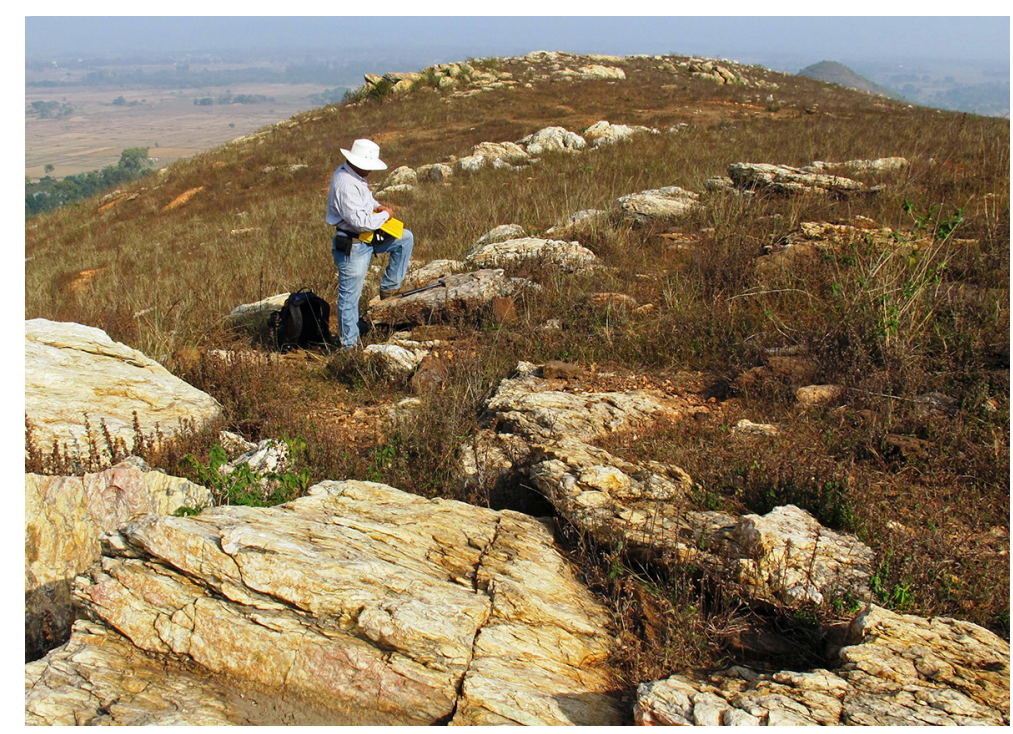

must consequently be deduced that the Bhurkuli succession cannot be considered to represent this intermediate river type.

Some of the characteristics of the Bhurkuli section (apart from the relatively high proportion of large pebbles) are well known from present-day anastomosing rivers, for instance regarding the width/depth ratio, which was measured in the Bhurkuli section to vary significantly, being of the order of 10-100). This ratio is mentioned for modern anastomosing rivers as dependent of the climate (Huisink, 2000; Mol et al., 2000; Van Huissteden \& Kasse, 2001; Boogaart et al., 2003), for instance 16 for the North Saskatchewan and the Upper Columbia rivers in a temperate humid climate (Smith \& Smith, 1980; Smith, 1983, 1986; Makaske, 1998), 28 for the Magdalena River in a humid tropical climate (Smith, 1986), 10 for Cooper's Creek (Rust, 1981) and 6-233 for the Fitzroy River in an arid climate (Taylor, 1999), and 70 for the Atawapiskat in a subarctic climate (King \& Martini, 1984). It is, nevertheless, not likely that the Bhurkuli conglomerates were deposited in an anastomosing river system, because present-day anastomosing rivers tend to deposit much more fine-grained sediment, to have lower width/depth ratios and to have more heterolithic (gravelly sandy) layers. Moreover, the commonly tabular shape of the Bhurkuli conglomerate layers is in contrast with the presence of multiple channels that characterise an anastomosing river (Makaske, 2001); this lack of clearly incised channels also hinders reconstruction of channel margins and overbank environments. The sediments therefore do not show the characteristics that are considered as diagnostic for anastomosing rivers (Smith, 1986; Makaske, 2001, 2015; Carling et al., 2014). Moreover, it has been argued that a tree-like vegetation is essential for the development of anastomosing rivers (e.g. Davies \& Gibling, 2011), and any vegetation, let alone a treelike vegetation, was obviously absent on Archaean continents,

On the basis of the above reasoning why the Bhurkuli succession must be fluvial, but does not represent a meandering, braided or anastomosing river system, it must be deduced that a river type must be held responsible that, under the non-biogenic conditions of the Archaean, differed from the types of fluvial system that exist nowadays.

\section{Discussion}

The sedimentological analysis of successions that are badly exposed and of which the geological context actually is not known, poses problems by definition. Our analysis consequently should be considered primarily as a starting point for further investigations. Yet, our observations are sufficiently detailed to rule out deposition of the conglomerates and the intercalated sandy schists in most depositional environments. Most important seems that a marine origin can be excluded. This is consistent with other analyses that suggest that the various conglomerates of presumably a comparable (Mesoarchaean, possibly Neoarchaean) age on the northern Singhbhum Craton have a continental origin. It should be kept in mind, however, that excluding a marine depositional environment for Archaean rocks is much more difficult with certainty than for Phanerozoic rocks, because of the lack of fossil material.

Since the conglomerates lack the characteristics of mass-transported sediments, and because there is no indication at all for a glacial origin (tills), the 
conglomerates (and consequently also the interbedded sandy schists) must have been deposited in a fluvial environment. There is, however, also a caveat regarding Precambrian fluvial environments: the lack of colonization of the continents by plants (let alone animals) and more fundamentally different environmental conditions (e.g., the composition of the atmosphere) and consequently of the weathering processes - with, in turn, consequences for susceptibility to erosion - must have affected the transport and depositional conditions of streams and consequently also of their deposits. It can therefore not be fully excluded that the present-day classification of rivers into meandering, anastomosing, wandering and braided rivers was less applicable to some of the Archaean streams, including those that deposited the Bhurkuli succession.

\section{Conclusions}

A succession of Archaean sediments near Bhurkuli (E India) accumulated in river systems which deposited alternating layers of clast-supported gravels (now conglomerates) and sandy clays (now sandy schists). The low degree of exposure, the isolated occurrences of the conglomerates, and the tectonic characteristics prevent detailed sedimentological observations that might increase the insight into the precise processes that controlled sediment transport and deposition by the rivers, but it is likely (because the sediment characteristics are not consistent with those of modern meandering, braided or anastomosing rivers) that a river system of a different type existed. The pebble characteristics of the various conglomerate units are partly different, suggesting alternating source areas.

The bad exposure of the rocks also prevents detailed structural observations, but the previous idea of Dunn (1929) that the conglomerates belong to one stratigraphical layer that was folded, could be falsified on the basis of the differences in pebble characteristics (pebble composition, shapes and sizes) of the various conglomerate layers. It appears that the total succession has, although some tectonic complications are present, a roughly constant structural position.

\section{Acknowledgements}

Fieldwork by A.J.v.L. was made possible by the Foundation Dr Schürmannfonds (The Netherlands) (grant no. 82/2012). SD is grateful to the Science and Engineering Research Board (SERB) (grant no. PDF/2016/002499/ EAS) and infrastructural support at Department of Sci- ence and Technology, Government of India, for financial support in the form of a Research Fellowship during his Ph.D. Programme and to the Earth and Environmental Sciences Department (IISER), Bhopal IISER, Bhopal and CSIR, NGRI, Hyderabad, for infrastructural support and a post-doctoral fellowship.

\section{References}

Acharyya, S.K., Gupta, A. \& Orihashi, Y., 2010. Neoarchaean-Palaeoproterozoic stratigraphy of the Dhanjori Basin, Singhbhum Craton, eastern India: and recording of a few $\mathrm{U}-\mathrm{Pb}$ zircon dates from its basal part. Journal of Asian Earth Sciences 39, 527-536.

Bhattacharya, H.N. \& Mahapatra, S., 2008. Evolution of the Proterozoic rift margin sediments - North Singhbhum mobile belt, Jharkhand-Orissa, India. Precambrian Research 162, 365-386.

Bhushan, S.K. \& Sahoo, P., 2010. Geochemistry of clastic sediments from Sargar supracrustals and Bababudan Group, Karnataka: implications on Archean Proterozoic boundary. Journal of the Geological Society of India 75, 829-840.

Bluck, B.J., 1971. Sedimentation in the meandering River Endrick. Scottish Journal of Geology 7, 93-138.

Boogaart, P.W., Van Balen, R.T. Vandenberghe, J. \& Kasse, C., 2003. Process-based modelling of fluvial system response to rapid climate change II. Application to the River Maas (The Netherlands) during the Last Glacial-Interglacial transition. Quaternary Science Reviews 22, 2097-2110.

Brierley, G.J., 1989. River planform facies models: the sedimentology of braided, wandering and meandering reaches of the Squamish River, British Columbia. Sedimentary Geology 61, 17-35.

Cailleux, A., 1945. Distinction des galêts marins et fluviatiles. Bulletin de la Société Géologique de France 15, 375-404.

Carling, P., Jansen, J. \& Meshkova, L., 2014. Multichannel rivers: their definition and classification. Earth Surface Processes and Landforms 39, 26-37.

Chakraborty, K.L., 1996. A comprehensive geological review of the Precambrian Banded Iron Formation (BIF) of Bihar and Orissa, eastern India. Indian Journal of Geology 68, 211-236.

Chakraborty, K.L. \& Majumder, T., 1986. Geological aspects of the Banded Iron Formation of Bihar and Orissa. Journal of the Geological Society of India 28, 109-133.

Chatterjee, R.S. \& Das, S., 2004. Tattekere conglomerate-quartzite association: origin and stratigraphic position of a disputed Archean formation in the supracrustals of Karnataka, India. Journal of Asian Earth Sciences 23, 247-261.

Cowan, D.S., 1978. Origin of blueschist-bearing chaotic rocks in the Franciscan Complex, San Simeon, California. Geological Society of America Bulletin 89, 1415-1423.

Davies, N.S. \& Gibling, M.R., 2011. Evolution of fixed-channel alluvial plains in response to Carboniferous vegetation. Nature Geoscience 4, 629-633. 
De, A., 1957. Conglomerate deformation in the western part of the Singhbhum shear zone. Proceedings of the Indian Science Congress, Abstract, 168-169.

Desloges, J.R. \& Church, M.A., 1989. Wandering gravel-bed rivers. The Canadian Geographer / Le Géographe canadien 33, 360-364.

Dobkins Jr., J.E. \& Folk, R.L., 1970. Shape development on Tahiti-Nui. Journal of Sedimentary Petrology 40, 1167-1203.

Dunn, J.A., 1929. Geology of North Singhbhum including parts of Ranchi and Manbhum Districts. Geological Society of India Memoirs 54, 1-166.

Dunn, J.A. \& Dey, A.K., 1942. The geology and petrology of eastern Singhbhum and surrounding areas. Geological Survey of India Memoirs (Hyderabad) 69, 281-456.

Eriksson, P.G., Mazumder, R., Sarkar, S., Bose, P.K., Altermann, W. \& Van der Merwe, R., 1999. The 2.7-2.0 Ga volcano-sedimentary record of Africa, India and Australia: evidence for global and local changes in sea level and continental freeboard. Precambrian Research 97, 269-302.

Huisink, M., 2000. Changing river styles in response to Weichselian climate changes in the Vecht valley, eastern Netherlands. Sedimentary Geology 133, 115-134.

King, W.A. \& Martini, I.P., 1984. Morphology and recent sediments of the lower anastomosing reaches of the Attawapiskat River, James Bay, Ontario, Canada. Sedimentary Geology 37, 295-320.

Leleu, S., Hartley, A.J. \& Williams, B.P.J., 2009. Largescale alluvial architecture and correlation in a Triassic pebbly braided river system, Lower Wolfville Formation (Fundy Basin, Nova Scotia, Canada). Journal of Sedimentary Research 79, 265-286.

Makaske, B., 1998. Anastomosing rivers; forms, processes and sediments. Nederlandse Geografische Studies 249. Koninklijk Nederlands Aardrijkskundig Genootschap/Faculteit Ruimtelijke Wetenschappen, Universiteit Utrecht, Utrecht.

Makaske, B., 2001. Anastomosing rivers: a review of their classification, origin and sedimentary products. Earth-Science Reviews 53, 149-196.

Makaske, B., 2015. Anastomosing pattern. In: H. Hargitai \& A. Kereszturi (Eds): Encyclopedia of planetary landforms. Springer (New York), 73-78.

Mazumder, R., 2005. Proterozoic sedimentation and volcanism in the Singhbhum crustal province, India and their implications. Sedimentary Geology 176, 167-193.

Mazumder, R., Bose, P.K. \& Sarkar, S., 2000. A commentary on the tectonosedimentary record of the pre-2.0 Ga continental growth of India vis-a-vis Pre-Gondwana Afro-Indian supercontinent. Journal of African Earth Sciences 30, 201-217.

Mazumder, R., Van Loon, A.J., Mallik, L., Reddy, S.M., Arima, M., Altermann, W., Eriksson, P.G. \& De, S., 2012. Mesoarchaean-Palaeoproterozoic stratigraphic record of the Singhbhum crustal province, eastern India: a synthesis. In: Mazumder, R., Saha, D. (Eds): Palaeoproterozoic of India. Geological Society, London, Special Publications 365, 31-49.

McCann, A.M. \& Kennedy, M.J., 2009. A probable glacio-marine deposit of Late Ordovician-Early Siluri- an age from the north central Newfoundland Appalachian Belt. Geological Magazine 111, 549-564.

Miall, A.D., 1977. A review of the braided-river depositional environment. Earth-Science Reviews 13, 1-62.

Miall, A.D., 2013. Fluvial depositional systems. Springer International Publishers (New York), 316 pp.

Mohapatra, K., Singh, P.P. Mishra, P. \& Mahant, K., 2008. Detrital iron-ore deposits in the Iron Ore Group of rocks, northern Orissa, eastern India. Australian Journal of Earth Sciences 55, 1139-1152.

Mol, J., Vandenberghe, J. \& Kasse, C., 2000. River response to variations of periglacial climate in mid-latitude Europe. Geomorphology 33, 131-148.

Mukhuopadhyay, D., Bhattacharya, T. Chakraborty, D. \& Dey, A.K., 1990. Structural pattern in the Precambrian rocks of Sonua-Lotapahar region, North Singhbhum, eastern India. Proceedings of the India Academy of Sciences - Earth and Planetary Sciences 99, 249-268.

Mukhopadhyay, J., Ghosh, G., Beukes, N.J., \& Gutzmer, J., 2007. Precambrian alluvial iron ores in the Singhbhum craton: implications for origin, age of BIF-hosted high-grade iron ores and stratigraphy of the Iron Ore Group. Journal of the Geological Society of India 70, 34-42.

Naha, K., Mukhupadhyay, D., Daastidar, S. \& Mukhuopadhyay, R.P., 1995. Basement-cover relations between granitoid gneiss body and its metasedimentary envelope: a structural study from the Early Precambrian Dharwar tectonic province, southern India. Precambrian Research 72, 283-299.

Nanson, G.C. \& Croke, J.C., 1992. A genetic classification of floodplains. Geomorphology 4, 459-486.

Reddy, I., Reddy, M.S., Satyaranrayana, G. \& Kalluraya, V.K.K., 2002. New find of conglomerate horizons in southern part of Cuddapah Basin and its stratigraphic significance. Journal of the Geological Society of India 59, 213-217.

Reimer, R.O., Condie, K.C., Schneider, G. \& Georgi, A. 1985. Petrography and geochemistry of granitoid and metamorphite pebbles from the early Archaean Moodies Group, Barberton Mountainland/South Africa. Precambrian Research 29, 383-404.

Roy, A.B. \& Bhattacharya, H.N., 2012. Tectonostratigraphic and geochronologic reappraisal constraining the growth and evolution of Singhbhum Archaean craton, eastern India. Journal of the Geological Society of India 80, 455-469.

Rust, B.R., 1981. Sedimentation in an arid-zone anastomosing fluvial system: Cooper's Creek, Central Australia. Journal of Sedimentary Petrology 51, 745-755.

Saha, A.K., 1994. Crustal evolution of Singhbhum-North, Orissa, eastern India. Geological Society of India Memoir 27, $341 \mathrm{pp}$.

Shrinivasan, R. \& Naqvi, S.M., 1990. Some distinctive trends in the evolution of the Early Precambrian (Archaean) Dharwar craton, South India. Developments in Precambrian Geology (Elsevier, Amsterdam) 8C, 245-266.

Sinha, K.K., Rao, N.K., Shah, V. \& Sunilkumar, T.S., 1997. Stratigraphic succession of Precambrium of Singh- 
bhum: evidence from quartz pebble conglomerate. Journal of the Geological Society of India 49, 599-589.

Smith, D.G., 1983. Anastomosed fluvial deposits: modern examples from Western Canada. In: J. Collinson \& J. Lewin (Eds): Modern and ancient fluvial systems. International Association of Sedimentologists Special Publication 6, 155-168.

Smith, D.G., 1986. Anastomosing river deposits, sedimentation rates and basin subsidence, Magdalena River, northwestern Colombia, South America. Sedimentary Geology 46, 177-196.

Smith, D.G. \& Smith, N.D., 1980. Sedimentation in anastomosed river systems: examples from alluvial valleys near Banff, Alberta. Journal of Sedimentary Petrology 50, 157-164.

Taylor, C.F.H., 1999. The role of overbank flow in governing the form of an anabranching river: the Fitzroy river, northwestern Australia. In: N.D. Smith \& J. Rogers (Eds): Fluvial sedimentology VI. International Association of Sedimentologists Special Publication 28, 77-91.

Van Huissteden, J. \& Kasse, C., 2001. Detection of rapid climate change in Last Glacial fluvial successions in The Netherlands. Global and Planetary Change 28, 319-339.
Van Loon, A.J. \& De, S., 2015. Archaean sedimentation on the Singhbhum Craton: depositional environments of conglomerates in Jharkhand (east India). In: R. Mazumder \& P.G. Eriksson (Eds): Precambrian basins of India: stratigraphic and tectonic context. Geological Society, London, Memoirs 43, 109-119.

Van Loon, A.J., Mazumder, R. \& De, S., 2012. Unravelling the depositional environment of the Archaean Rajkharsawan conglomerate (Jharkhand, E India). Netherlands Journal of Geosciences 91, 129-135.

Vasudev, V.N. \& Chadwick, B., 2008. Lithology and structure of the auriferous Hutti Schist belt, northern Karnataka: implications for Neoarchaean oblique convergence in the Dharwar craton, South India. Journal of the Geological Society of India 71, 239-256.

Wentworth, C.K.,1922. A method of measuring and plotting the shapes of pebbles. United States Geological Survey Bulletin 730 C, 91-102.

Widera, M., 2010. The morphology of fossil pebbles as a tool for determing their transport processes (Koźmin South lignite open-cast pit, central Poland). Annales Societatis Geologorum Poloniae 80, 315-325.

Manuscript received: 13 October 2016 Revision accepted: 15 June 2017 